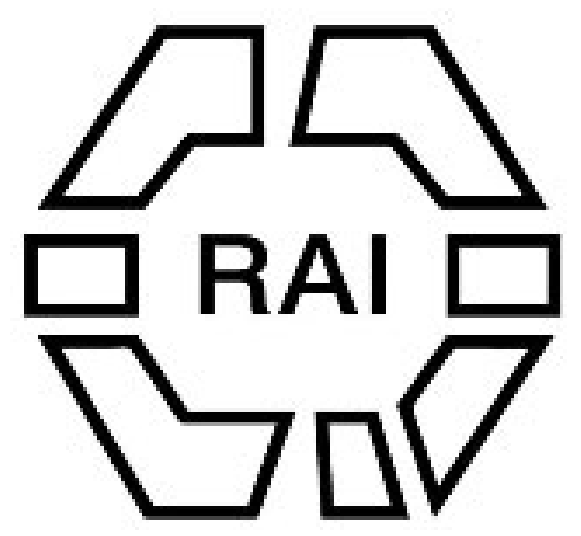

On the Signification of Couvade

Author(s): H. Ling Roth

Source: The Tournal of the Anthropological Institute of Great Britain and Ireland, Vol. 22 (1893), pp. 204-243

Published by: Royal Anthropological Institute of Great Britain and Ireland

Stable URL: http://www.jstor.org/stable/2842049

Accessed: $14 / 06 / 2014$ 16:11

Your use of the JSTOR archive indicates your acceptance of the Terms \& Conditions of Use, available at http://www.jstor.org/page/info/about/policies/terms.jsp

JSTOR is a not-for-profit service that helps scholars, researchers, and students discover, use, and build upon a wide range of content in a trusted digital archive. We use information technology and tools to increase productivity and facilitate new forms of scholarship. For more information about JSTOR, please contact support@jstor.org.

Royal Anthropological Institute of Great Britain and Ireland is collaborating with JSTOR to digitize, preserve and extend access to The Journal of the Anthropological Institute of Great Britain and Ireland. 


\section{On the Signification of Couvade.}

By H. Ling Roth.

\section{I.}

Couvade, or male child-bed, is the name given to a variable custom which prevails among many peoples, and which generally ordains that upon the birth of a child the father must take to his sleeping corner and there behave as though he had suffered the pangs of labour. Occasionally he is only obliged to fast, almost invariably he is restricted in his diet, and generally he is not allowed to follow his usual vocations. In some cases he commences fasting before his wife is confined, or even before marriage; in other cases the woman is also restricted to the use of certain foods. Simultaneously with the husband's lying-in the wife gets up and resumes her domestic duties, but it also happens occasionally that husband and wife lie-in together. The duration of the state of couvade varies considerablyfrom a few days to several weeks, or up to the time the navel string of the child falls off, or even up to the time at which the child can sit upright. The word couvade in its present signification was first used by Dr. E. B. Tylor ("Early Hist. of Mankind," London, 1865), and when the original meaning of the word is remembered it will be thought a more appropriate word could hardly have been adopted.

To the so-called civilised portion of humanity the custom appears exceptionally barbarous in its treatment of the suffering wife, and at the same time it appears extremely absurd. So absurd does it seem to us that everyone on first reading about it smiles incredulously as though some traveller's tale were being recited.

But the effect on the woman is nothing like what we imagine it to be, for among savages we find almost everywhere that women are delivered with little pain or trouble. Quandt, during his twelve years' sojourn in Surinam, knew of no death of a native woman in child-birth ("Nachricht von Surinam," p. 252). Brett says child-birth was no hardship, and quotes the example of an Indian mother rising and going about her duties immediately after delivery ("Indian Tribes of Guiana," p. 101). H. H. Bancroft, the anthropologist, cites cases among the North American Pacific Indian women where child-birth hardly affects the mother ("Native Races of the Pacific States," i, pp. 111, 197, 242, 391, 412, 436, 513, 566, 703, 773; ii, 267, 678). Amongst the Abipones the case was somewhat different; here 
the women were accustomed to ride astraddle which habit resulted in malformation and consequent suffering during delivery, but once delivered the woman suffered no more (Dobritzhoffer, "Gesch. d. Abiponer," Vienna, 1873, ii, p. 269). The Australian women have little difficulty in child-birth, and death from such a cause is exceedingly rare ("Journ. Anthrop. Inst.," xiii, 1864, p. 280); the same is said of the Sepoy wives in India (Walter Campbell, "Indian Journal," Edin., 1864, p. 361) ; of women on the Gold Coast (W. Smith, "Voy. to Guinea," Lond., 1774, pp. 211, 266); on the Gambia (Fr. Moore's "Travels," Lond., 1738, pp. 35, 134); in the South Seas (Wilson's "Miss. Voy.," pp. 157, 339); in the African Lake Regions (Burton, "Lake Regions," ii, p. 23) ; while of the Nicobarese Mr. E. H. Man tells us : "In child-bearing it would seem that from the extreme rarity of fatal terminations or of slow recoveries, labour may be regarded as comparatively easy" ("Journ. Anthrop. Inst.," May, 1889, xviii, p. 378). On the other hand, I am told, Dr. Livingstone mentions a few cases attended with fatal results.

It is a popular belief that the wives of savages, like the majority of those of the civilised working classes, do not suffer in delivery, because being much given to hard work they do not feel the pangs of labour in the same way as the better cared for women of the civilised upper classes. But this appears to be a mistake, for in Dr. Galabin's "Manual of Midwifery" (ed. 1886, p. 84) we read: "The increase in the size of the brain which goes with civilisation and intellectual development involves greater pain, difficulty, and risk in parturition, for it requires a corresponding increase of size in the skull, and although the pelvis undergoes some corresponding enlargement, yet this does not keep up fully with the head. In savage races not only is the head smaller on the whole, but there is a relatively less development of the anterior cerebral lobes, and the forehead is therefore flatter. . . ." Dr. Rollin appears to have been the first to point out that the ease with which the North American Pacific Indian women were delivered was due to the uncommonly large dimensions of the pelvis as compared with that of their European sisters (Perouse, "Voy.," Lond., 3rd ed.,1807, iii, p. 207).

On this part of the question an eminent London professor writes me: "Savages, like animals, undoubtedly suffer much less from most of the ills that civilised flesh is heir to, toothache for instance; indeed if they had such constitutions as many of us possess, in consequence of the accumulations, through many generations, of various morbid tendencies, they could not exist in the conditions of life to which they are exposed. With us the evil and the alleviation go hand in hand to a great extent. VOL. XXII. 
Ceteris paribus, painful labour does seem an indication of a certain amount of elevation in the scale of civilisation. 'Return unto thy lore, which says that ever the most perfect thing has joy most keen and suffering most sore' (Dante)."1

We may therefore, in the inquiry before us, safely put on one side any reflections as to the apparent indifference of the husband with regard to his wife's sufferings, for the treatment she puts up with is practically no special hardship to her, and keeping our minds free from all consideration as to the woman's share in the custom we shall be better able to understand the peculiar ideas which cause the father to act in so extraordinary a fashionjudged according to our notions. As the custom itself in its various modifications will be best understood by a survey of its geographical distribution, I will proceed to describe its variations under that condition.

II.

1. Europe-Until quite recently it has been believed by anthropologists that the custom not only existed in times gone by in the Basque country, but that it was still to be found there at the present day. ${ }^{2}$ Professor Vinson has, however, shown very conclusively ("Études de Linguistique," Paris, 1878, p. 197) that such is not the case, and as has been pointed out by Dr. J. A. H. Murray “"Academy," Nov. 19, 1892 , No. 1072 , p. 459), even the accepted statement of Strabo is open to doubt as to whether that geographer really referred to the custom in question. Some years ago I inquired of a Scotch engineer, who had spent many years amongst these people, and he very emphatically denied its existence or that any custom or belief which could in any shape or form be misconstrued into the custom. Nor can I find that any moderu traveller mentions the custom as existing in this part of the world. Dr. Ploss ("Das Kind," Stuttgart, 1875, i, p. 128)

1 As a side issue may we infer from the frequent allusions to painful labour in the Old Testament, especially in the book of Jeremiah, that the Jews have alwars held a high place in the scale of civilisation?

2 According to M. Quatrefages the Basque people practise couvade ("Revue des Deux Mondes," 1850, i, p. 1084). M. Michel repeats Quatrefages word for word, but Dr. E. B. Tylor has pointed out that, according to Vinson, the modern Basques do not practise couvade, and also that the writers on the subject during the last two centuries refer to the Bearnais and not to the Basques ("Researches," 3rd ed., p. 301). Laborde, writing at the commencement of the century, says it was customary among the Cantabrian women, and likewise common among the inhabitants of Navarre ("View of Spain," Lond., 1809, ii, p. 383). C. Val. Flaccus ("Arg. Lib.," v, 148) and Apoll. Rhod. ("Argonautica," ii, 1009) state it was an Iberian custom; Diodorus Siculus $(v, 14)$ says it was practised by the natives of Corsica at the beginning of the Christian era. For evidence as to the value of these writers the student is referred to the late correspondence in the "Academy." 
says Fr. v. Maltzan describes it in his work, "Sardinien," but I cannot find the reference, and Dr. E. B. Tylor tells me Maltzan distinctly states couvade does not exist in that island. ${ }^{1}$

2. Asia.-In Borneo, Spencer St. John found it among the Land Dyaks of Sirambau ("Life in Forests Far East," 2nd ed., $i$, p. 170). "The husband of the pregnant woman, until the time of her delivery, may not do work with any sharp instrument, except what may be absolutely necessary for the cultivation of his farm; he may not tie things together with rattans, or strike animals, or fire guns, or do anything of a violent character, all such things being imagined to exercise a malign influence on the formation and development of the unborn child. The delivery is attended by an old woman, called Penyading, or mid-wife. A fowl is killed, the family tabooed for eight days, during which time the unfortunate husband is dieted on rice and salt, and may not go out in the sun or even bathe for four days; the rice and salt diet is to prevent the baby's stomach swelling to an unnatural size."

For the evidence of the existence of couvade in this part of the world it will be as well to refer to the paper on couvade by the late Professor Wilken, who brings forward a mass of new information about the custom in the Indian Archipelago. As he gives so much which is quite new, but which is not easily accessible to English readers, I have translated and give below the most important portions of his paper:-

"The Alfoeros of Boero must be named first. This is what Schouten, who touched on the island in the middle of the seventeenth century, says of the custom: "The black woman in her confinement also does not remain in her bed, but henceforth goes with her new-born child to the river, and she, when she has well washed both the child and herself, returns to her usual occupation, and yet no harm follows. Still, besides I am truly assured, that as the little darkie of the island of Boero begins to thrive a little, from that time forward the man, as husband of the confined woman, very absurdly pretends to be ill, and allows himself to be right handsomely pampered, so that the blockhead is waited upon more than usual. In the meanwhile the black woman must to her work in order to prepare delicacies for her husband, in order to put the poor fellow on his legs again.' This account was confirmed by Captain Van der Hart. Those

1 The editor of the "British Medical Journal," September 12th, 1891, p. 626, says: "Isolated instances are found, where the custom occurs, even in England at the present day." I have not heard of any instances, although the following came under my notice at Halifax not long ago: $-\mathbf{A}$ woman was confined one night, and the following morning she walked down to the mill where her husband usually worked in order to excuse him, as he had to go to bed because she had disturbed him in the night! 
who in 1850 made a voyage round Celebes and to some of the Moluccas met again at Boero with that which W. Schouten had, in his time, come across there, 'Although,' says he among other things, 'there are almost two centuries gone by since W. Schouten visited the island, civilisation does not seem to have gained during this long period so much ground as it has done in other parts of the Indian Archipelago.' So also V. der Hart confirms the still existing belief in the legend of the noly crocodile amongst the Alfoeros of which Schouten speaks in his itinerary. So also the couvade seems still, according to him, to be practised in the island. 'As soon as a child is born,' says he, at least, ' there is not so much trouble made as with us in Europe; the mother immediately after her delivery goes with her child to the river, both wash themselves, and therewith the affair is finished. . . . Coming back from the river the mother goes about her usual duties; the man, on the other hand, behaves sickly (as infirm) and absurdly, as though he had been confined, enjoys with much gusto the delicacies which are prepared for him by his wife.' How far the custom is still practised in Boero is not shown. During my sojourn in the island I omitted to make special inquiry about it. In I)r. Riedel's work there is also no mention made of it. It is said, on the contrary, that after the confinement the man as well as the woman perform their daily work. In the meanwhile it appears, as I have already elsewhere observed, the communications of Dr. Riedel chiefly relate to the Alfoeros of the southern regencies, so that it is very likely that couvade still exists amongst the tribes of the north of that island. ${ }^{1}$

"Before leaving the Moluccas we have to refer to some traces of couvade amoncst a few other peoples. Thus we find amongst some of the inhabitants of the south-west islands, principally those of Leti and Kissner, it is mentioned that when a woman is confined, superstition forbids her husband for some months to plough, to dig, to hoe, \&c.2 As a survival of couvade is further to be considered the custom found in the Timor-laut islands where the father at first has to carry and take care of the child, while the mother, after she has bathed, performs her usual housework. ${ }^{3} \quad$ Amongst the natives of the Uliasers, natives of the Amboynas, we finally see how the man during the preg-

1 Van der Hart's account is so similar, word for word, with Schouten that it would seem he had merely copied out the words without ascertaining their present application to the alleged circumstances. Van der Hart does not say he observed the custom, and neither does Professor Wilken say he observed it, so I think we may hold it doubtful whether the custom still exists on the island.

2 "Mededeelingen van wege het Nederlandsche Zendelinggenootschap," dl. xx, blz. 250 , en dl. xxviii, blz. 194.

3 Riedel, "De sluik-en kroesharige rassen tusschen Selebes en Papua," blz. 304. 
nancy of his wife is obliged to abstain from a number of things. $\mathrm{He}$ is forbidden, so we read, 'to manufacture objects such as tables, chairs, doors, windows and such like of same nature too, in similar obligation to bring together, to join, or, in order to drive in anywhere, a peg or nail for fear lest the woman might have a difficulty in labour.' So may he, as is told us later on, not be allowed to split bamboos, in order, for example, to make a fishhook, lest the child have a harelip. Nor is it with any eye to the child['s welfare], ]awful for him when in sight of the child to open cocoanuts, to cut hair, or to hold the rudder of a vessel. ${ }^{1}$

"That couvade may also have been practised in the Philippines appears from a few customs. Of the tribes of the interior of North Luzon, more especially of the province Bontok, we read to be sure: 'Hat eine Frau geboren, so geht sie mit dem Kinde an den Fluss, wäscht sich und das Kind, kehrt in die Rancherie zurück, übergiebt das Kind dem Manne und geht an ihre Arbeit; nur um Nahrung zu geben, nimmt es die Mutter, der Mann pflegt es, trägt es, in eine Decke gehüllt, auf dem Rücken und empfängt auch die Besuche der Freunde und Bekannten, während die Frau auf dem Felde arbeitet. ${ }^{2}$ It is further said of the Tagalas that not only the mother but also the father, 'gewisse Regeln aus Rücksicht für seine Nachkommenschaft zu beobachten hat; so muss er den Genuss auffällig zusammengewachsener Früchte unterlassen, weil seine Frau ihm sonst Zwillinge gebären konnte, was bei den Tagalan durchaus nicht gern gesehen wird. ${ }^{3}$

"Among the Bahau Dyaks, in the valley of the Mahakam, the abstinence customs are limited to the period after the confinement. Then the man must not drink any water for three days, and for five months afterwards use no salt, nor chew any sirih, nor smoke, while also he is not permitted to eat with anyone, nor to have any intercourse with a woman. As soon as the child has arrived at the age of five months the father is free to follow his ordinary mode of life. ${ }^{4}$ Something similar seems to hold good amongst the Dyaks of Sanggau in Borneo's western regency. At a confinement a father gets into that state known as pantang or pemali, that is, according to the meaning of the word, in a state wherein certain actions are forbidden

1 Van Schmid, "Aanteekeningen, nopens de zeden, gewoonten en gebruiken, benevens de vooroordeelen en bijgeloovigheden der bevokling van de eilanden Saparoea, Haroekoe en Noessa Laut," Tideschr.v. Nederl. Indië, Jahrg. 15.43, dl. ii, blz. 527-528; Ludeking, "Schets van de residentie Amboina," blz. 16:

2 Schadenberg, "Beiträge zur Kenntniss der im Innern Nordluzons lebenden Stämme." Verh. der Berliner Gesell. für Anthrop. Ethn. u. Urgeschichte, Jahrg. 1888, blz. 35.

3 Blumentritt, "Sitten und Brauche der Tagalen," Ausland, Jahrg. 1885, blz. 1017.

4 Bock, "Reis in rost-en Zuid Borneo," . . . blz. 97-98. 
lim. Thus for example for four days he is not allowed to leave the village. ${ }^{1}$ It is otherwise in the valley of the Baritoe among the Olo-Ngadju, Also among them the man has to observe some abstinence, but not after, but before the birth of the child. Different things are then forbidden, pali, to him as well as to the pregnant woman, so that the child should not suffer the detrimental consequences and be transformed into a monster, pahingen. Neither parent must on any account kindle or approach a fire-stherwise the child would come spotted into the world; nor eat any kind of fruit-lest the child should suffer from belly-ache; nor make any holes in wood-lest the child be born blind; nor dive under water, nor hold other bodies under water-lest the child be stifled in its mother, etc. ${ }^{2}$

"Turning to the western portion of the Archipelago we find the same prohibitory customs among the Nias ${ }^{3}$ people as amongst the Olo-Ngadjus. 'Eigenthümlich," says Dr. Schreiber, ' ist die Besorgniss des Vaters für sein noch ungeborenes Kind. Man meint, dass zwischen ihm und seinem Kinde die innigste Sympathie besteht, und desswegen muss der Vater bei allen, was er thut oder was ihm begegnet, auf sein Kind Rïcksicht nehmen. ${ }^{4}$ They have then a series of customs and prescriptions during pregnancy, which not only the woman but the man must accurately attend to, so that the birth should be attended with good results, and that all possible calamities to the child in later life be warded against. Amongst others they must abstain from many things, must not touch certain foods, nor visit certain spots, nor may they touch certain objects, \&c. Likewise they may not kill a pig, snake, hen, or fly, nor plant any bamboo trees, nor drive in a nail anywhere, nor carpenter, nor look at themselves reflected in the water, nor pass by a spot where a mar. has been murdered, nor by a place where a buffalo or any other animal has been killed, \&c. All these unlawful acts are indicated by the word mamoni. Should any of these prescriptions be contravened by the man or the woman, various misfortunes would ensue; the placenta might remain behind in the womb, the child might be still-born, or it might be born with a bodily deformity, such as harelip, a stiff neck, crooked legs, cross-eyed, or the child might be attacked with convulsions, skin eruptions ur ophthalmia. The non-observance of these decrees may in itself have a prejudicial influence on the child until its fourth

1 Bakker, "Het rijk Sanggau," Tidsch. v. Ind. T. L. en. Vk., dl. xxix, blz. 415.

2 Perelaer, "Ethnographische Beschrijving der Dajaks," blz. 38-39, en " Hardeland, Dajaksch Woordenboek," i. v. pahingen.

3 It is a curious fact that while Modigliani ("Un Viaggio a Nias," p. 556) alludes to couvade as practised elsewhere, in no way does he say that any kind of courade is practised in the island of Nias.

* Schreiber, die Insel Nias, "Petermann's Mitheilungen," dl. xxiv, blz. 50. 
year, and the time during which the punishment may fall due depends on the moment when the infringement took place during pregnancy, in such manner that neglect in observing the decree during the first month of pregnancy affects the new-born child during the eighth month of its life, a neglect in the middle of pregnancy affects the child in the second year, while neglect at the end of pregnancy exposes the child to all sorts of dangers in the fourth year of its life. All these mishaps can be averted by sacrifices. ${ }^{1}$

"To conclude, we have to bestow our attention on the OrangBenu-wa of Malacca and the Boeginese and Macassarese. Of the first-named, more especially of the Jakuns, who inhabit the province Johor along the river Madek, we read they have the following superstition which, so long as children are unable to walk, prevents their parents from using as food certain fish and animals; as soon as the little ones have acquired the use of their legs this restriction is removed, and the parents are once more able to indulge in what has so long been pantang or forbidden. Should this superstition not be complied with, and any parent eat of any of the forbidden creatures during the period of restriction, the children are supposed to be liable to an illness called busong, arising, according to the Malays, from perrut-Këmbung or swollen stomach. ${ }^{2}$ Concerning the Boeginese and the Macassarese these people believe that the man, during the pregnancy of his wife, and she also, often behaves whimsically, and has desires, appetites for foods which otherwise are not eatena belief, as will presently appear, that may have had some connection originally with couvade. ${ }^{3}$

"When we trace the cited examples, we see that couvade occurs most completely among the Alfoeros of Boero while everywhere else only a few traces of it can be shown. The man must, either before the confinement of his wife (among the inhabitants of the Oeliassers, Tagala, Olo-Ngadju and the Niasers), or afterwards (among the inhabitants of the south-western islands, the Bahau Dyaks, the Dyaks of Sanggau, and the Orang Benu-wa of Malacca) deny himself many things. In a single case (among the Land Dyaks of Sarawak) the customs of abstinence are observed both before and after the confinement,

1 Durdik, "Genees-en verloskunde bij de Niasers," Geneeskundig Tijdschrift vcor Nederl. Indië, dl. xxii, blz. 268-270. Besides in the already cited essay of Dr. Sehreiber, further information is found on this custom in the papers ofChatelin, "G:sdsdienst en Bijgeloof der Niasers," Tijdschr. v. Ind. T. L. en Vk. dl. xxvi, blz. 158-160 ; 'Thomas, "Sitten u. Aberglauben auf Nias," Globus xxxix, blz.14; Sunderman, "Die Insel Nias, Allegemeıne Missionschrift," dl. xi., blz. 423.

2 Hervey: "The Endau and its tributaries," "Journ. Straits Branch Roy. Asiatic Soc.," 1881, p. 120.

3 Matthes, "Makassarische en Boegineesche Woordenboeken," i. vv.irang en ideng. 
Among two folks (the natives of Timor-laut and the tribes of Bontok in North Luzon) nothing more has survived of the custom than the fact that the father in the early days has to carry and look after the child while the mother goes about her usual occupations. In many cases these customs seem to have become mechanical survivals, without any kind of significance being attached thereto. It is different with some peoples (the, inhabitants of the Oeliasers, Tagala, Land Dyaks of Sarawak Olo-Ngadju, the Niasers and the Orang-Benu-wa) who have the belief that the rites and commandments to be observed by the man are necessary for the well-being of the expected or newborn child, a belief-just to refer to it in passing-which is met with likewise elsewhere, where couvade exists, among others, as appears from that already stated, the tribes of Guiana."

Marco Polo describes the custom in Zardandan, probably between Thibet and Manzi, where the husband keeps his bed for forty days (Yule's "Marco Polo," second edition, Lond., 1875 , book II, ch. xl, p. 70): "And when a woman among them has borne a child, they wash it and swathe it, and she rises and goes about her tasks, whilst the husband takes to bed, keeping the child with him, and lies so for forty days, and is visited by all his kith and kin, and they have great feasting and jollity, and this they do because, say they, the woman has gone through great travail, so it is right that the man also should suffer his share." In this respect Colonel Yule points out (ibid., p. 75) that the Langzi, aborigines in the department Weining, also do the couvade for a month, and he states that the Miris men on the Upper Assam border lie-in for forty days. Mr. A. $R$. Colquhoun states that couvade exists among the Miaos, in the extreme south-east of Yunnan, but it would appear he is quoting from Marco Polo, for he does not say that he met with or heard of the custom on his travels. He quotes the wellknown lines in "Hudibras": "Chineses go to bed, and lie in, in their ladies' stead." Another writer, Mr. W. Lockhart, in a paper on the aborigines of China ("Trans. Ethn. Soc.," London, 1861 , p. 181) speaks of a tribe who practise couvade. His assertion rests on the authority of a "Chinese traveller among: the Miautsé," whose name is not given." Captain Neale ("Residence in Siam," Lond., 1852, p. 155) refers to the " curious anecdote told of the Chinese, for the truth of which, however, no one has yet been able to vouch. They say when a Chinese lady is blessed with an increase in her family, from the moment

1 Professor R. K. Douglas refers to this author and the custom among the Miao-Tze and kindred tribes in a paper entitled "Quaint Customs in KweiChow" in "Cornhill Magazine," p. 95, January, 1872. He writes me that so far as he is aware there is no trace of the custom among the Chinese pure and simple. 
of her accouchement the unhappy husband is put to bed also, and there detained for forty days, and during this delightful penance he is subjected to all the rigorous treatment of his better half. Should medicine be administered to her he must partake of it also, and he is strictly confined to the same diet she is obliged to undergo."

The Rev. John Batchelor thus describes it among the Ainu: "A curious custom used to exist amongst this people. As soon as a child was born the father had to consider himself very ill, and had, therefore, to stay at home, wrapped by the fire. But the wife, poor creature! had to stir about as much and as quickly as possible. The idea seems to have been that life was passing from the father into his child" ("The Ainu of Japan," Lond., 1892, p. 44).

In Southern India, where Telegu is spoken, the wandering Erukala-vandhu observe the custom : "Directly the woman feels the birth-pangs she informs her husband, who immediately takes some of her clothes, puts them on, places on his forehead the mark which the women usually place on theirs, retires into a dark room, where there is only a very dim lamp, and lies down on the bed, covering himself up with a long cloth. When the child is born, it is washed and placed on the cot beside the father, assafotida, jaggery, and other articles are then given, not to the mother, but to the father. During the days of ceremonial uncleanliness the man is treated as the other Hindus treat their women on such occasions. $\mathrm{He}$ is not allowed to leave his bed, but has everything needful brought to him." (The Rev. John Cain, “Indian Antiquary," May, 1874, p. 151.) Dr. E. B. Tylor ("Researches," second edition, p. 301) says : "The account, for which I have to thank Mr. F. W. Jennings, describes it as usual among natives of the higher castes about Madras, Seringapatam, and on the Malabar Coast. It is stated that a man, at the birth of his first son or daughter by the chief wife, or for any son afterwards, will retire to bed for a lunar month, living principally on a rice diet, abstaining from exciting food and from smoking; at the end of the month he bathes, puts on a fresh dress and gives his friends a feast. ${ }^{1}$ The people of this district of India may be described as mainly of the indigenous Dravidian stock, more or less mixed with Aryan Hindu. They are Hinduised to a great degree in religion and habits, but preserve some of their earlier customs, among which couvade, which is not known as an Aryan Hindu practice, must probably be counted. An ancient Asiatic people recorded to

1 "The details are from a nurse, born of English parents in India, and acquainted with Indian habits." 
have practised the couvade are the Tibareni of Pontus, ${ }^{1}$ at the South of the Black Sea, among whom, when a child was born, the father lay groaning in bed with his head tied up, while the mother tended him with food and prepared his baths."

In New Britain "there are certain times when a man of this tribe may not go fishing, when one of his women is enceinte or during the fall of the moon ..... In the former case the man must stop at home to prevent the spirits taking away the life of the expected baby, by sucking its breath from it; if the child dies in spite of all his precautions, they say he did not fight for it enough with the spirits" (Powell, "Wanderings in a Wild Country," Lond., 1883, p. 207). This fighting for the life of the new born child sounds something like Paul de la Gironière's account of the Tagals (mixed Malays) under similar conditions, viz.: "One often sees an Indian when his wife is in the throes of childbirth, seated astride on the roof of his house, sabre in hand, cutting and thrusting in empty air, to drive away, as he says, the Assuan. Sometimes he continues this exercise for several hours, until the accouchement is over" ("Twenty Years in the Philippine Islands," Lond., 1853, p. 73).

In his paper on the Nicobar Islanders ("Journ. Anthrop. Inst.," xviii, 368), Mr. E. H. Man (to whom all anthropologists are deeply indebted for his investigations among the Andamanese and Nicobarese) says: "Couvade is practised by all the communities at the Nicobars, including the inland tribe of Great Nicobar; it is by them regarded as a custom of remote antiquity, and is called oto in the dialect of the Central Group."

Desirous of obtaining some more specific information on the custom as practised by these islanders, I wrote to Mr. Man, who not only obliged me with the notes which follow, but enhanced my obligation to him by courteously affording me permission to publish them in this Paper. He writes :-

"Although never, I believe, mentioned or even known to previous writers, the singular custom called 'couvade' or paternal lying-in is among the institutions of the Nicobarese; it is called falngendre and is practised at Car Nicobar, as also in the Southern Islands of the group; the period extends over some two weeks for a first child, during which time the man may not work nor cook, but lies up like an invalid, while

1 “Strabo," iii, 4, 17.

"In the Tibarenian land, When some good woman bears her lord a babe, 'Tis he is swathed and groaning put to bed; Whilst she arises, tends his baths, and serves Nice possets for her husband in the straw." Apoll. Rhod. "Argon," ii, 1012.

("Quarterly Review," July, 1868, p. 249.) 
he and his wife are fed by their relatives. If a man marries a second wife after having had children by the former marriage, the couvade, upon his again becoming a father, is curtailed to a couple of days."

After writing the above, Mr. Man paid a further visit to the Nicobars (autumn, 1892), where he was able again to substantiate the correctness of his information, and then very kindly wrote me as follows :-

"Among the Nicobarese couvade is likened to the sitting of a hatching hen. At Nancoury the husband must remain as an invalid for about five days, during which he may not work, nor chew betel, nor bathe, and he has his food cooked for him and brought to him. He may feed his wife with what is thus cooked and brought to him. After this and until his wife is able to resume her ordinary duties he must still refrain from leaving the village, or from joining in any entertainments, and he can only perform work of a light nature, but may eat what food he likes.

"A day or more before the confinement, in order to ensure an easy labour, the lashings of the husband's and her uwn property, e.g., canoes, spears, waterpots, and even of the hut, etc., are cut, and they are renewed soon after the birth of the child.

"The food forbidden to a woman from the time of her confinement till she resumes her duties a month or so later, are fish (including turtles and crabs), fowl and cocoanut. Her drink consists of hot water and her food of vegetables, fruit, rice, pandanus, and pork.

"At Car Nicobar it is much the same, only there the husband remains idle and has his food cooked for him for about one month. He may bathe two days alter the birth of his child.

"In some cases husbands consider it advisable to observe greater precautions by commencing to do little or no work a few months before their wife's expected confinement, more especially abstaining from any such work as felling trees and digging holes for hut posts.

"The belief is that if the father failed to observe the custom of couvade the child would be liable to fits, and were the infant to ail or die under such circumstances, it would certainly be attributed to the father's failure to observe the practice.

"Similar observances are found throughout the group. The Nicobarese are not matriarchal. The mother looks after the child, assisted by her female friends. Some slight modifications occur in the case of a man's first child. The observance is less strict in the case of a man who has a child by a second wife, if he has had children by his late wife." 
3. Africa.- "In the Kingdom of Cassange, where the Giaghi live, the husband takes the place of the woman delivered, as soon as she gets up, and he is then served and cared for by the mother as though he had been confined." The author of this statement, Father A. Zuchelli, appears to have made it on hearsay, for he continues that if he had met such a man he would have thrashed him ("Relazione del Viaggo e Missione di Congo," Venezia, 1712, “7th Rel.," $\$ \mathrm{xv}$, p. 118; in Germ. edit., pp. 165-6) which sounds very much like the thrasbing the Abate Gilij said he gave a South American father for his belief in the custom (ii, p. 133), and looks as though Zuchelli were using the latter's words.

In his work entitled "Africana," Vol. i, p. 14, the Rev. Duff MacDonald says that in some African tribes "a father has to fast after the birth of his child or take some such method of showing that he, as well as the mother, should take care of the young stranger." But on my writing to him for particulars, Mr. MacDonald replied under date of 16 Nov., 1891, that in the above passage he was only referring in a general way to peculiar customs, and that he himself had not observed the custom of couvade. Neither Dr. Schweinfurth nor Dr. Junker speak of the custom in their travels, but Dr. Felkin writes me in answer to my enquiries: "In the Shuli district the women are held in high esteem. They are looked up to by the men, and counsel is taken of them in most of the affairs of life. In this district to the best of my belief, couvade really exists, because for some days before and after a child's birth the father remains in or near the hut, refrains from certain kinds of meat (what I do not know), and generally takes care of himself, that the infant may not be harmed. Again amongst the Dinkas a somewhat similar custom obtains. For two or three days after the birth of a child, the father remains in the hut, pays great attention to it, and nurses it. My attention was not called to the subject in any other place, and I made no special inquiries with regard to the custom (28th September, 1891)."

Dr. Ploss ("Das Kind,” p. 130) says H. Bancroft describes the custom in South Africa, but as H. Bancroft only wrote about America, the reference here must be a misprint.

The Rev. J. Sibree informs me that he has not met with so much as a trace of couvade in Madagascar, and he has lived there nearly twenty years and is intimately acquainted with the customs of the natives.

4. America.-In the New World the custom is met with almost throughout the length and breadth of the Continent.

In Greenland the husbands of the women suffering delivery 
" must forbear working for some weeks, neither must they drive any trade during that time" (H. Egede's "Greenland," Lond., 1745, p. 192).

According to Mig. Venegas, the Californian women, beyond washing themselves and the newborn child, "went about their duties as usual, and in other particulars observe no manner of caution, going to the forest for wood and food, and performing every other service the husband wanted; whilst he in the meantime lay in his cave, or stretched at full length under a tree, affecting to be extremely weak and ill ; and this farce continued for three or four days " ("Hist. of Calif.," Lond., 1759, i, pp. 81-2). Among the Central Californians, "when childbirth overtakes the wife, the husband puts himself to bed and there, grunting and groaning he affects to suffer all the agonies of a woman in labour. Lying there, he is nursed and tended for some days as carefully as though he were the actual sufferer" (Bancroft, "Native Races," i, p. 391,) but among the Southern Californians "although the husband did not affect the sufferings of labour, his conduct was supposed in some manner to affect the unborn child, and he was consequently laid under certain restrictions, such as not being allowed to leave the house, or to eat fish and meat" (ibid., p. 412). Under the same circumstances the Lagunero and Ahomana husbands "remain in bed for six or seven days, during which time they neither eat fish nor meat" (ibid., p. 585).

In Ecuador " the couvade is rife among the Jivaros; and at the birth of a child, the mother has to undergo all her parturient troubles outside the house, exposed to the elements, whilst the husband quietly reclines in the house, coddling and dieting himself for some days until he has recovered from the shock produced upon his system by the increased weight of his responsibilities as a father. This custom is still in some measure extant in many of the civilised villages on the Solimons, where amongst the Tapuyos and even degrees more approached to the whites, the father on the birth of a son or daughter lays himself in the hammock, from which he will not move on any consideration to do any kind of work, nor especially to touch any cutting instrument, fearing thereby to exercise evil influences upon the healthy development of the child" (A. Simson, "Journ. Anthrop. Inst.," ix, 1880, p. 388). Mr. Simson also describes the custom among the Piojés of the Putumayo, thus: "Another very curious custom is that of both father and mother fasting for days after the birth of a child. Sometimes this is kept up so long that it is a wonder that at least the mother does not sink under the debilitating ordeal. If the father is away from his wife he also fasts three days on hearing the news that she has 
borne him a child, as some of the Piojés assured me" ("Journ. Anthrop. Inst.," viii, 1879, p. 222).

In the West Indies, Thevet appears to have been the first to mention the custom as existing among the Caribs ("Cosmographie Universelle," Paris, 1575, ff. 915-916). Rochefort gives the following account of it: "C'est qu'au meme tems que la femme est delivrée le mary se met au lit, pour s'y plaindre et y faire l'accouchée: coutume, qui bien que sauvage et ridicule, se trouve neanmoins ì ce que l'on dit parmy les paysans d'une certaine Provence de France. Et ils appellent cela faire la couvade. Mais ce qui est facheus pour le pauvre Caraïbe, qui s'est mit au lit au lieu de l'accouchée, c'est qu'on luy fait faire, diété dix ou douze jours de suite, ne luy donnant rien par jour, qu'un petit morceau de cassave, et un peu d'eau, dans laquelle on a aussi fait bouillir un peu de ce pain de racine. Après il mange un peu plus: mais il n'entame la cassave qui luy est presentée, que par le milieu durant quelques quarante jours, en laissant les bords entiers qu'il pend à sa case, pour servir au festin qu'il fait ordinairement en suite à tous ses amis. Et meme il s'abstient après cela, quelquefois dix mois, ou un an entier, de plusieurs viandes comme de Lamantin, de Tortuë, de Pourceau, de Poules, de Poisson, et de choses delicates: Crajonant par une pitoyable folie, que cela ne nuise à l'enfant. Mais ils ne font ce grand jeusne qu'à la naissance de leur premier enfant. Car à celle des autres, leurs jeusnes sont beaucoup moins austère et beaucoup plus courts, n'etant d'ordinaire que de quatre ou cinq jours au plus . . . Quelques uns de nos Caraïbes ont encore une antre folie : et c'est bien pis que tout le reste pour le pauvre père à qui il est né un enfant, car à la fin du jeusne, on luy scarifie vivement les epaules avec une dent d'Agouty. Et il faut que ce miserable, non seulement se laisse ainsi accomoder, mais que meme il le souffre sans temoigner le moindre sentiment de douleur. Ils crnyent que plus la patience du père aura paru grande dans ces épreuves, plus recommandable aussi sera la vaillance du fils : Mais. il ne faut pas laisser tomber à terre ce le noble sang, dont l'effusion fait aussi germer le courage. Aussi le recueillent ils en diligence, pour en frotter le visage de l'enfant, estimant que cela sert encore beaucoup à le rendre genereus" ("Hist. Nat. et Mor. des Iles Antilles de l'Amerique." Rotterdam, 1665 , p. 550). Du Tertre, whose "Histoire Générale des Antilles," \&c., was published in Paris two years after Rochefort's work, gives an account of the custom in almost identical words (ii, pp. 371-374). Labat mentions the custom, but states he did not see it carried out ("Nouveaux Voyages," La Haye, 1724, ii, p. 123). Chavallon, writing one hundred years later than Rochefort, says that among the Caribs in Martinique, as 
soon as the woman has brought forth, she gets up and looks after all the requirements of the household while the husband lies-in and remains in bed for some time in her stead ("Voyage à la Martinique," Paris, 1763, p. 53).

Of the existence of the custom in South America, Ant. Biet, writing in the middle of the seventeenth century, says: "Quand la femme mariée reconnoist qu'elle est enceinte, elle se declare à son mary qui fuit alors beaucoup de superstitieuses, craignant que l'enfant qu'elle porte ne perisse. Il s'abstint de manger de. plusieurs choses; il fait une penitence etroite; il craint de toucher les gros poissons comme le Lamantin, la Tortuë, et semblables. Ils ne veulent point s'approcher de ceux qui les pechent, de peur, disent ils que leurs enfants ne meurent et que leurs ames n'entrent dans ces poissons," and he continues, when the woman has been delivered "Le mary pend son lit au plus haut de la case, s'y va coucher; et fait l'accouchée six semaines, et au lieu de faire servir la femme qui ne garde point le lict, elle le sert luymesme durant tout ce temps-là, pendant lequel il ne se leve que pour aller à ses necessitez. Quand il passe au milieu de tous ses cohabitans, il ne les regarde pas, ne levant pas les yeux. Il jeune etroitement pendant ces six semaines, ne mangeant que fort peu, d'ou vient que quand sa couche est faite, il se leve maigre comme une squelette: alors il sort et est obligé d'aller tuer une sorte d'oyseau pour sa relevée" ("Voy. de la France Equinoxiale en l'Isle de Cayenne." Paris, 1664, pp. 389, 390). Ph. Firmin is the next author who writes about the custom. His account is to be found in "Description de Surinam" (Amsterdam, 1769, i, p. 81). But Quandt's account of the custom as practised in Surinam differs in a material point from that of all previous writers, inasmuch as he states that the husband, not being allowed to do this and that and so on, finds it best to go to bed, and then he is certain to be out of temptation's way, thus: "Denn wenn eine Indianer Frau ein Kind bekommt darf ihr Mann keinen Baum fällen, keine Flinte Iosschiessen, und kein grosses Wild jagen, weil sonst das Kind krank werden und sterben würde. Es ist ihm nur erlaubt, in der Nähe mit dem Pfeil kleine Vögel zu schiessen und kleine Fische zu angeln. Er ist also mehrentheils zu Hause, und da seine Hangmatte gewöhnlich sein Stuhl und sein Lager ist; so ist ihm in dièser müssingen Zeit nichts bequemer, als in derselben zu liegen, und die Frau sitzt auf der Erde im Sande, um ihre Hangmatte nicht zu verunreinigen, zumal sie gemeiniglich dass neugeborene Kind darin liegen hat" ("Nachricht von Surinam," Görlitz, 1808, pp. 252-3).

Richard Schomburgk's account of the custom in British Guiana reads very much like that of Rochefort written 200 
years previously, differing mainly in the fact that, whereas the latter states the friends of the husband scratch him with Agouti teeth, the former tells us the wretched man is not allowed to scratch himself with his own nails, but may do so with Agouti teeth. The similarity between these two accounts is explained when we remember that Dr. Brinton has pointed out that the aborigines of Hispaniola or Hayti (a part of the Greater Antilles) described by Rochefort were Arawaks, practically the same people described later on by Schomburgk. ${ }^{1}$

The Rev. W. H. Brett's description of the custom is interesting from several points of view. He says: "Some of the men of the Acawois and Caribi nations, when they have reason to expect an increase of their families, consider themselves bound to abstain from certain kinds of meat, lest the expected child should in some mysterious way be injured by their partaking of it. The Acouri (or Agouti) is thus tabooed, lest like that little animal, the child should be meagre; the Haimara also, lest it should be blind, the outer coating of the eye of that fish suggesting film or cataract; the Labba, lest the infant's mouth should protrude like the labba's, or lest it be spotted like the labba, which spots would ultimately become ulcers; the Marudi is also forbidden, lest the infant be still-born, the screeching of that bird being considered ominous of death. Both the above tribes and the Waraus consider it their duty to abstain from venison after their wives are confined, lest the child on arriving at manhood be found wanting in speed, exemplified by the slow pace which the female deer when she has a young fawn at her feet is obliged to observe. Such are some of the dietetic rules laid down for the men by their system of superstition. They are probably observed by very few in their full rigour, for the forbidden animals form a large proportion of the Indian's bill of fare as found in the forests, and a Carib or other polygamist with three or four wives might be debarred from tasting them during the whole, or the best period, of his manhood" ("Indian Tribes of Guiana," Lond., p. 355). Mr. E. F. im Thurn has quite recently fully confirmed and amplified Mr. Brett's statements ("Among the Indians of Guiana," Lond., 1883, p. 218), and adds that the Macusi abstain from venison even before marriage.

Southey, quoting as his authority the "Noticias do Brazil," says: "Immediately upon a woman's delivery the father takes to his hammock, covers himself up, and is nurst there till the navel string of the infant has dried away; the union between him and his progeny is regarded as so intimate that the utmost

1 "The Arawak Language of Guiana in its Linguistic and Ethnological Relations." By D. G. Brinton, Philadelphia, 1871. 
care must be taken of him lest the child should suffer" ("History of Brazil," i. p. 238). Von Tschudi mentions casually that at childbirth the Peruvian husband goes to bed and allows himself to be cared for a few weeks ("Peru," 1846, ii, p. 235). According to Spix and Martius ("Reise in Brasilien," Th. iii, p. 1339), "Wie die Cariben und die alten Tupis haben die männlichen Mundurucus die Sitte, sich bei der Geburt eines Kindes mehrere Wochenlang in die Hangmatte zu legen und die Pflege der Wöchnerin, so wie die Besuche der Nachbarn, anzunehmen." Among the Passés "die Wöchnerin bleibt nach Geburt ein Monatlang im Dunkeln, und ist, wie der Gatte, auf die kost von Mandiocca, Beiju, und Tocacaz (Caldoz de Farinha), angewiesen. Dieser färbt sich schwartz und bleibt während der ganzen fast Zeit oder bis dem Säuglinge die vertrocknete Nabelschnur abfällt, sechs bis acht Tage in der Hangmatte" ("Martius' Ethnographie,” i, p. 511). Dobritzhoffer tells us the Abipones followed the custom ("Gesch. der Abiponen," Vienna, 1783, ii, pp. 273--5). Speaking generally of the Brazilians, Laet, writing in 1633, says: "After the birth of the child father and mother fast until the navel has healed, and sometimes up to the eighth day" ("Novus Orbis," Book $\mathrm{XV}$, ch. xii, p. 544). The male Puris, Coropos and Coroados do not lie-in, but fast with their wives at childbirth ("Spix and Martius', op. cit.," Theil i, p. 381), and the Marauhas, Omaguas, and Cauixanas behave similarly ("Martius' Ethnographie," i, pp. $427,428,441,482)$.

Regarding the custom among the Coimbas in Peru, St. Cricq's words are: "A l'heure de son accouchement, quand la femme, abritée par son moustiquaire, est seule à lutter contre la douleur, l'époux, accroupi au seuil de la hutte, attend dans une immobilité complète et l'observation du jeûne le plus rigoureux que sa compagne soit delivrée et lui annonce le sexe de l'enfant." If it be a girl the father spits on it, if a boy the mother is congratulated; on returning from washing "elle félicite à son tour le père de l'enfant," that is, if it be a boy (“Bull. Soc. Géog.," Paris, 1853, 4th Series, vi, p. 288).

\section{III.}

From this survey it would seem in the first place that we want a great deal more information about the custom in the widely isolated cases where it has been reported, and, secondly, that the authenticity of some of the reported cases is doubtful in consequence of authors repeating their predecessors' tales, as Colquhoun did Marco Polo's, and V. der Haart did Schouten's. I should not be at all surprised if ultimately both Polo's and VOL. XXII. 
Schouten's accounts turned out to be myths, both these travellers making their records at a time when the Old World was full of the tales of the New, so that in the end we may yet find the custom is not, nor ever has been, so widespread as is generally supposed to have been the case.

In the Old World, couvade is only met with in isolated and widely separated localities; ; in the New World, it is to this day, more especially in South America, distributed over the length and breadth of the land. In Australia it appears to be positively unknown. In Asia we find it mostly in places where, owing to long isolation, customs, may, so to speak, have become crystallised; but the custom cannot by any means be attributed to such isolation, for the Caribs who follow the custom in its fullest extent are of a warlike disposition, and for the four hundred years during which they have been known to Europeans they have been known as rovers and are consequently by no means an isolated people. ${ }^{1}$ The custom does not appear to exist or to have existed among those people to whom the term " most degraded" is erroneously applied, people which were better described as savages living in the lowest known forms of culture, such as the Australians, Tasmanians, Bushmen, Hottentots, Veddahs, Sakeys, Aetas, and Fuegians. Neither does the custom exist among the so-called civilised portion of mankind. In other words couvade appears at first sight to be limited to peoples who hold an intermediate position between those in the highest and those in lowest states of culture. As such it may be considered to represent an intermediate or transition state of mental development.

But to follow out the geographical distribution it may be well to consider the purity of descent of the races affected. In Asia, Africa, and in Oceania, the populations are so mixed that we frequently find the most dissimilar branches of mankind living side by side as close neighbours, and perhaps only in such isolated cases as those of the Andamans, Tasmanians, Aetas, Veddahs, and Ainus, \&c., can we be tolerably certain that we are dealing with a fairly aboriginal population in situ. While in Africa at the present day "there is a principle of unity which embraces well nigh all the population," that country has

1 A curious illustration of the way in which peoples living side by side influence each other is given by Wallace ("Amazons and Rio Negro"Appendix), who, after speaking of the beliefs regarding the actions of pregnant women, says : "Many of these peculiar practices and superstitions are retained with much tenacity even by those Indians who are nominally civilised and Christian, and many of them have been even adopted by the Europeans resident in the country. There are actually Portuguese on the Rio Negro who fear the Indian pagés, and who fully believe and act on all the Indian superstitions respecting women." 
been ethnologically revolutionised, but within itself, almost as much as Europe or Asia. In America we have the fairest evidence for believing that not only is the so-called Indian population aboriginal, but that it forms one homogeneous whole, although some ethnologists are still inclined to regard it as a subdivision of the Mongolian. With regard to Australia and Tasmania, Messrs. Howitt and Fison, if I understand them correctly, seem to take it for granted that Australia was uninhabited when the present black population spread over the country ("Migrations Kurnai Ancestors," "Journ. Anthrop. Inst.," May, 1886, and the same Journal, xii, Aug., 1882, p. 40 ), but the result of other inquiries tends to indicate that the Australians drove their predecessors, the late Tasmanians, out of the mainland ("Aborigines of Tasmania," Lond., 1890, ch. xii ; Quatrefages, " Races Humaines," p. 368 ; Flower, "Presidential Address," pp. 384-386, Anthrop. Inst., 1885).

Geographically speaking therefore, we can understand how it is that in America the custom is so widespread, and, on the contrary, that in Asia and Oceania it is so isolated, but we have difficulty in accounting for its rarity in Africa, if it really do exist there, and its absence in Australia. In the former continent we should expect to find it in isolated corners as we do in Asia, while in Australia we should expect to find it covering the length and breadth of the land as in South America. Of the Tasmanians, it is now unfortunately apparently too late to discover whether they had any custom similar to couvade.

To sum up, we appear to get no explanation of the origin or distribution or meaning of the custom when we examine it from a geographical standpoint. Nor does, on the other hand, an ethnological examination throw much light on the question.

\section{IV.}

The latest system of the classification of mankind is, I believe, that adopted by M. Quatrefages in his "Histoire des Racrs Humaines," published at Paris in 1889. In this classification he has practically confirmed the general arrangement described by Prof. Sir William Flower in his presidential address to the Anthropological Institute in January, 1885. But while Sir Wm. Flower strictly adheres to three great primitive types with a permissible fourth (the American) M. Quatrefages, more for the sake of ease in handling his subject, makes three great divisions and two sub-divisions, consisting of the Mixed American and the Mixed Oceanic races. The divisions are as follows :-Black, Yellow, White, Mixed Oceanic, and American. 
i. The Black Race comprises the Indo-Melanesian (Nerrito, Dravidian, Tasmanian, Papuan, \&c.), the Australian, and the African. ii. The Yellow Race comprises the Siberian (Mongol, Turk, \&c.), the Thibetan, Indo-Chinese, and American-Inuit. iii. The White Race comprises the Allophyllic (Canaries, Asiaticn-American, Sinic, Indonesian, Circassian, Euskarian, \&c.), the Finn, the Semitic, and the Aryan. iv. and v. The terms Mixed Oceanic and American explain themselves.

If we now allocate the peoples who practise the custom of couvade in this classification, we get the following result :-

i. The Black Race; Dinkas, Shulis.

ii. The Yellow Race; Esquimaux (Greenlanders), Miris, \&c. iii. The White Race; Tibareni.

iv. The Mixed Oceanic Race; Miao-Tze, Malays, Dyaks, Tagals, Nicobarese, N. Britain Islanders, \&c.

v. The American Race; Most tribes probably.

The above tells us very little. It would appear we have a couple of supposed cases among the Black Race, a few among the Yellow Race, none authentic among the White Race, and numerous cases both in the Oceanic and American Races. Ethnologically, therefore, we are unable to gather any information regarding its origin.

\section{V.}

The reasons assigned for practising the custom are as varied as the custom itself, and the explanations offered by travellers who have met with it, as well as by those who have studied it, are widely divergent. Marco Polo was informed that the origin of the custom in Zardandan was due to the fact that the woman having had a hard time of it, it was only fair that the man should have his share of the suffering (op. cit., book ii, ch. 40, p. 70). In the Antilles, Du Tertre states the father was debarred from a variety of animals as food lest by his partaking of them the child should afterwards display as vices the peculiar weaknesses of these animals (op. cit., pp. 373-4). This interpretation agrees very thoroughly with that found to exist in Guiana by Messrs. Brett and im Thurn. Biet, as we have seen, says the father is not allowed to eat certain large fish, for fear in case the child were to die, its spirit would enter into one of these fish. Quandt thought male child-bed arose out of the desire to keep the men near their wives at childbirth, in order to help them; the men being prevented from bringing home large fish or game, as the women should at this period not be overburdened with work 
(op. cit., p. 253), and the men, being further debarred from exercising their usual vocations and restricted in their diet, found it best to take to their hammocks altogether. Chavallon argues that, as the Caribs believe that certain foods partaken by the father will affect the welfare of the new-born child, it follows that other acts on the part of the father will likewise have their effect hence from mere dietetic restrictions the father proceeds to take to his hammock, where he has not the means, and is out of the temptation, to expose his child to danger. He says some might conjecture that the law against certain foods was established especially so that the women should also abstain, and thereby keep the child from participating in evil results. Firmin (op. cit., i, p. 81), thought simply the custom a proof of the servitude of the woman and of the conceit of the man.

Spix and Martius say that among the Mundurucus the custom arose from the idea these people entertained that the child is solely the father's, the mother's share in the bearing and bringing forth being likened unto that of the earth, which in plant life simply receives the seed. This is the view Southey found recorded, thus: "It was their opinion that the child proceeded wholly from the father, receiving nutrition indeed and birth from the mother, but nothing more (op. cit., i, p. 218), from which Dr. Ploss argues the custom may have arisen out of a desire on the part of the community to make the father answerable by his conduct for the welfare of the child (op. cit., i, p. 138).

When Dr. E. B. Tylor first investigated the custom, he wrotethe explanations "almost all involve giving over the parentage to the father, and leaving the mother out of the question. This was an ancient Egyptian opinion, as Southey points out when mentioning its most startling development in the practice of the Tupinambas of Brazil, who would give their own women as wives to their male captives, and then without scruple eat the children when they grew up, holding them simply to be of the flesh and blood of their enemies." ("Early Hist.," Lond., third ed., p. 299.) Among the Khonds, however, this idea is quite reversed, for their Meriah captive women are allowed to live until they have borne children to Khond fathers; these children are then reared for sacrifice, but never put to death in the village of their birth," \&c. (John Campbell, "Wild Tribes of Khondistan," Lond., 1864.) Nevertheless were couvade an Australian institution, Southey's view would appear to be supported by the statement of Mr. Howitt, who, writing on the Australian class systems, says: "It is necessary to keep in view the fact that these aborigines, even while counting 'descent,'-that is counting the class names-through the mother, never for a 
moment feel any doubt, according to my experience, that the children originate solely from the male parent, and only owe their infantine nurture to their mother " " Journ. Anthrop. Inst.," xii, May, 1883 , p. 502).

In a very able and remarkable paper read before the British Association in 1889 , Dr. E. B. Tylor gives support to the old interpretation of the custom of couvade as expounded by Bachofen: "I must now," he says, " argue that the original interpretation of the couvade given by Bachofen in his great treatise in 1861, and supported by Giraud-Teulon, fits substantially with the facts, and is justified by them. He takes it to belong to the turning-point of society when the tie of parentage, till then recognised in maternity, was extended to take in paternity; this being done by the fiction of representing the father as a second mother. He compares the couvade with the symbolic pretences of birth, which in the classical world were performed as rites of adoption. To his significant examples may be added the fact that among certain tribes the couvade is the legal form by which the father recognises a child as his. Thus this apparently absurd custom, which for twenty centuries has been the laughingstock of mankind, proves to be not merely incidentally an indicator of the tendency of society from maternal to paternal, but the very sign and record of that change."

The above explanation of the custom of couvade has an almost irresistible power of convincing us of its correctness, for firstly it interprets the custom as "a very sign and record" of mankind's transition from one social state to another, in other words, it is made symbolic of one of the most important social changes mankind has been a party to, and secondly, it apparently settles a question which has hitherto been a veritable Chinese puzzle, and one which anthropologists have long attempted in vain to solve.

In a small way this new interpretation of the custom appears to be supported by the action of certain tribes, the Mundurucus for example, among whom "couvade is the legal form by which the father recognises the child as his." But against this one apparently reasonable explanation given by the savages themselves we have twenty-seven ${ }^{2}$ others which, if not reasonable to us, are equally as reasonable to the tribes who hold them as that of the Mundurucu is to him. Under such circumstances it will

${ }^{1}$ In an explanatory note Mr. E. B. Tylor relegates his old explanation that the custom of couvade implies a physical bond between parent (father) ard child to a secondary position, so that " the sympathetic prohibitions may be interpreted as originally practised by the mother only, and afterwards adopted by the father also ("Journ. Anthrop. Inst.," xviii, Feb. 1889, p. 256), thus inverting Chavallon's view.

${ }^{2}$ I have taken this figure, as 28 represents the sum total oi tribes practising couvade referred to in Dr. E. B. Tylor's paper. 
be more logical to decline to accept any explanation coming from the people themselves, but to argue from the known surroundings of the people, as such surroundings and belief react on the belief in couvade. In British Guiana couvade is still practised to this day by the Arawaks, Macusi, Warraus and True Caribs, but while the Arawaks count descent strictly in the female line, the other appear not to do. so that arguing from the Arawak two customs (couvade and female descent), it cannot by any means be said that couvade is the sign of the change from the maternal to the paternal, for among this tribe we have as yet no visible sign of any such impending change (see Table II). An examination of the custom as practised in Melanesia would seem to lead to the conclusion that cuuvade and the change go hand in hand, were it not for Mr. Codrington's very emphatic assertion that the people who indulge in couvade aro still decidedly matriarchal (Table III, col. 3).

But if Bachofen's theory as to the origin of couvade be the. correct one, how is it that (while the greater, if not the better, part of the evidence, which is leading anthropologists to the conclusion that mankind generally traversed the stage of descent through the females prior to descent through the males, comes from the study of the Australians) in that important paper on "From Mother-Right to Father-Right," by Messrs. Howitt and Fison ("Journ. Anthrop. Inst.," Aug., 1882, xii) we are not favoured with a single word about couvade, or anything at all approaching it? From the paper of these gentlemen, and from succeeding papers by $\mathrm{Mr}$. A. W. Howitt. we learn that a large portion of the Australians is in the transition stage (the MaternalPaternal of Dr. E. B. Tylor), yet we find no trace of the custom among these people, nor do we indeed find anywhere any reference at all to it in any account of the customs of these aborigines.

\section{VI.}

Mr. im Thurn has suggested (Timehri I, p. 313) that as there are other practices followed by savages, apparently allied to couvade, these should be included in the study of the custon. He then goes on to relate a case known to him where an Indian woman with child was not allowed to eat of the booty obtained by her. husband's dog lest the dog lose its power of hunting, a case which was also met with by Mr. R. L. Kingston (ibid. II, p. 355), and also reported by Mr. A. R. Wallace ("Amazon and Rio Negro," London, 1854, pp. 501-2). Mr. im Thurn also says (ibid., I, p. 313) that a pregnant Indian woman may step over the most poisonous snake and it will not bite her. This 


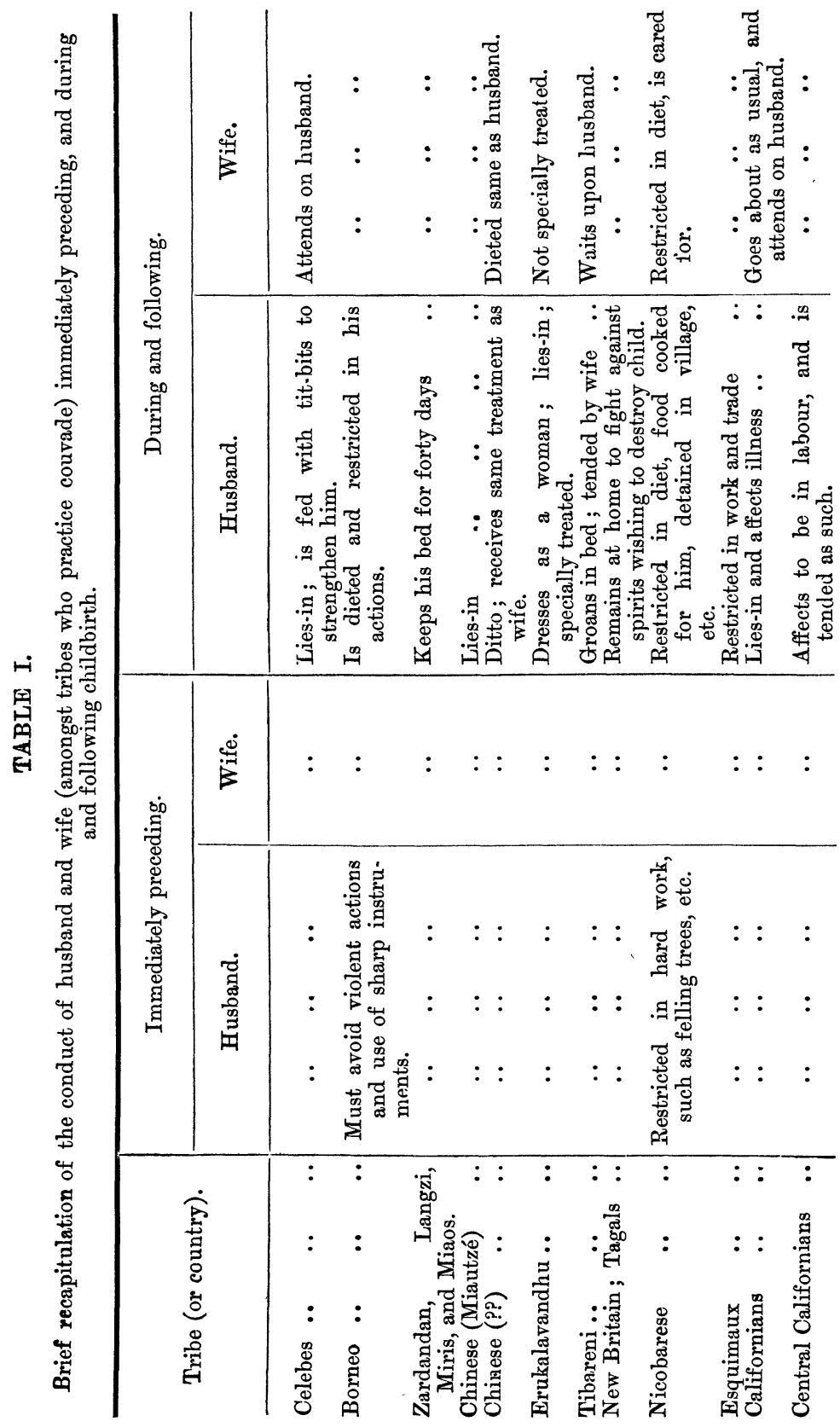




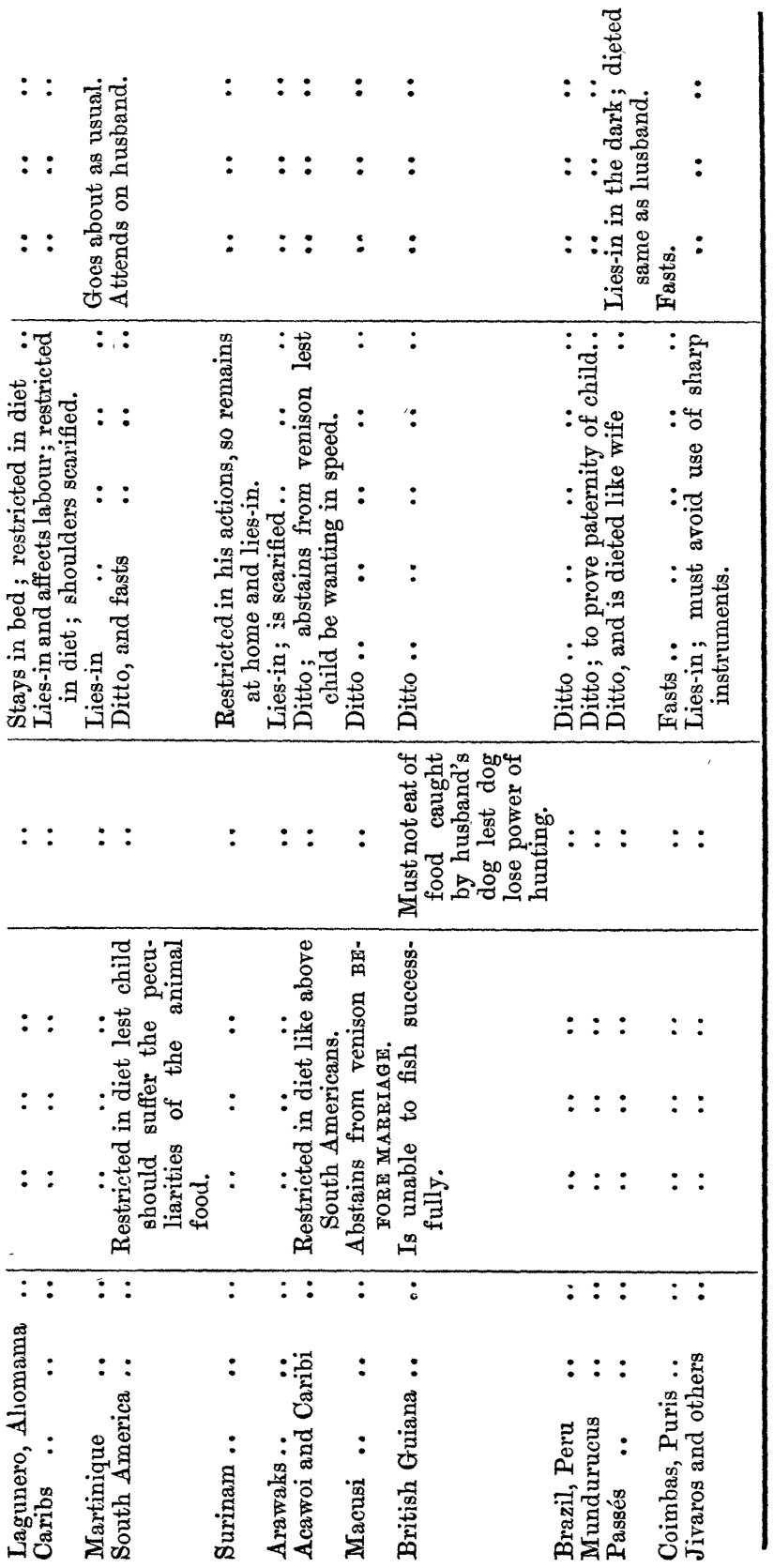


H. LING Roth.-On the Signification of Corivade.

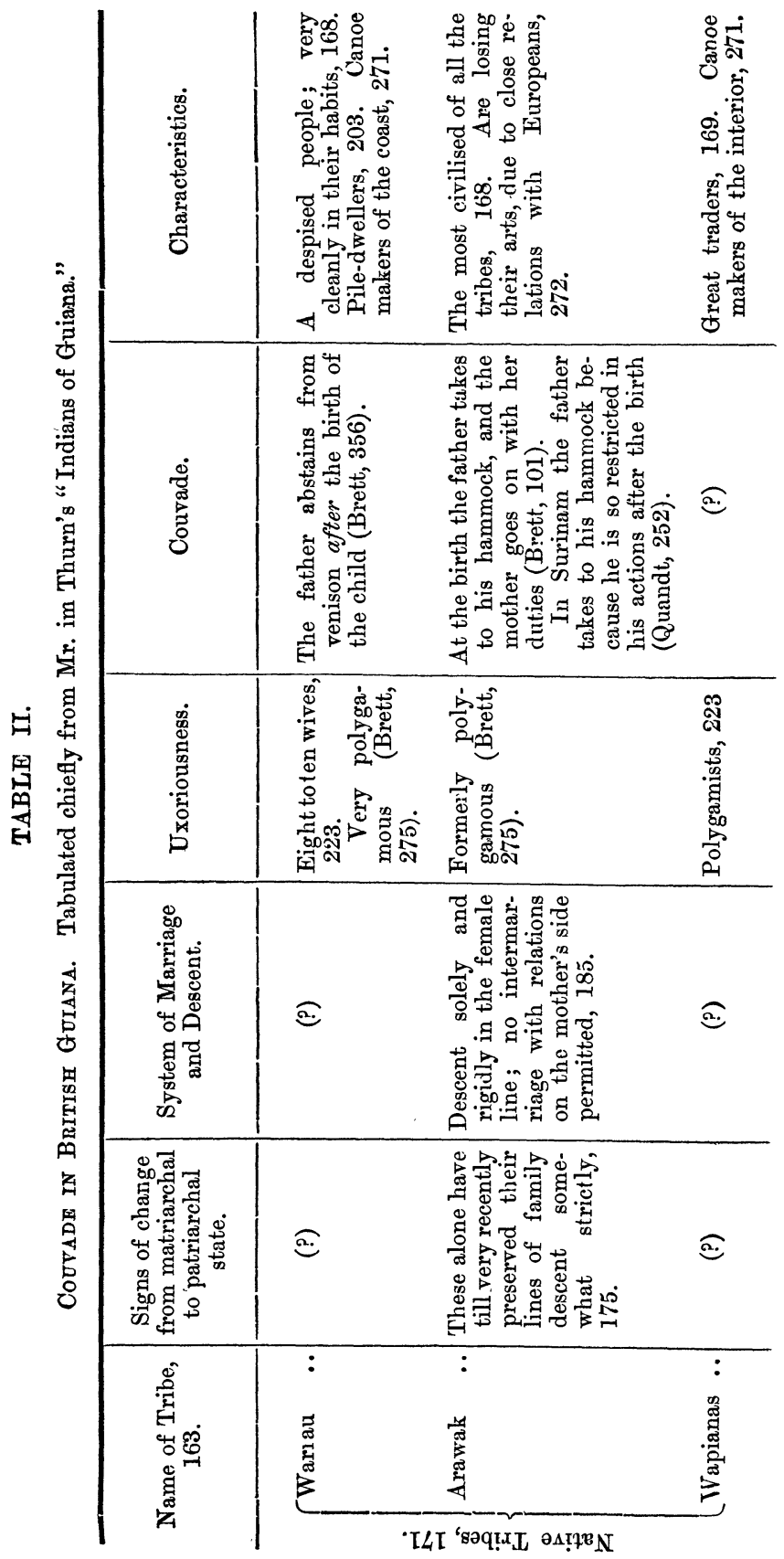


H. LiNG RoTH.-On the Signification of Couvade. 231

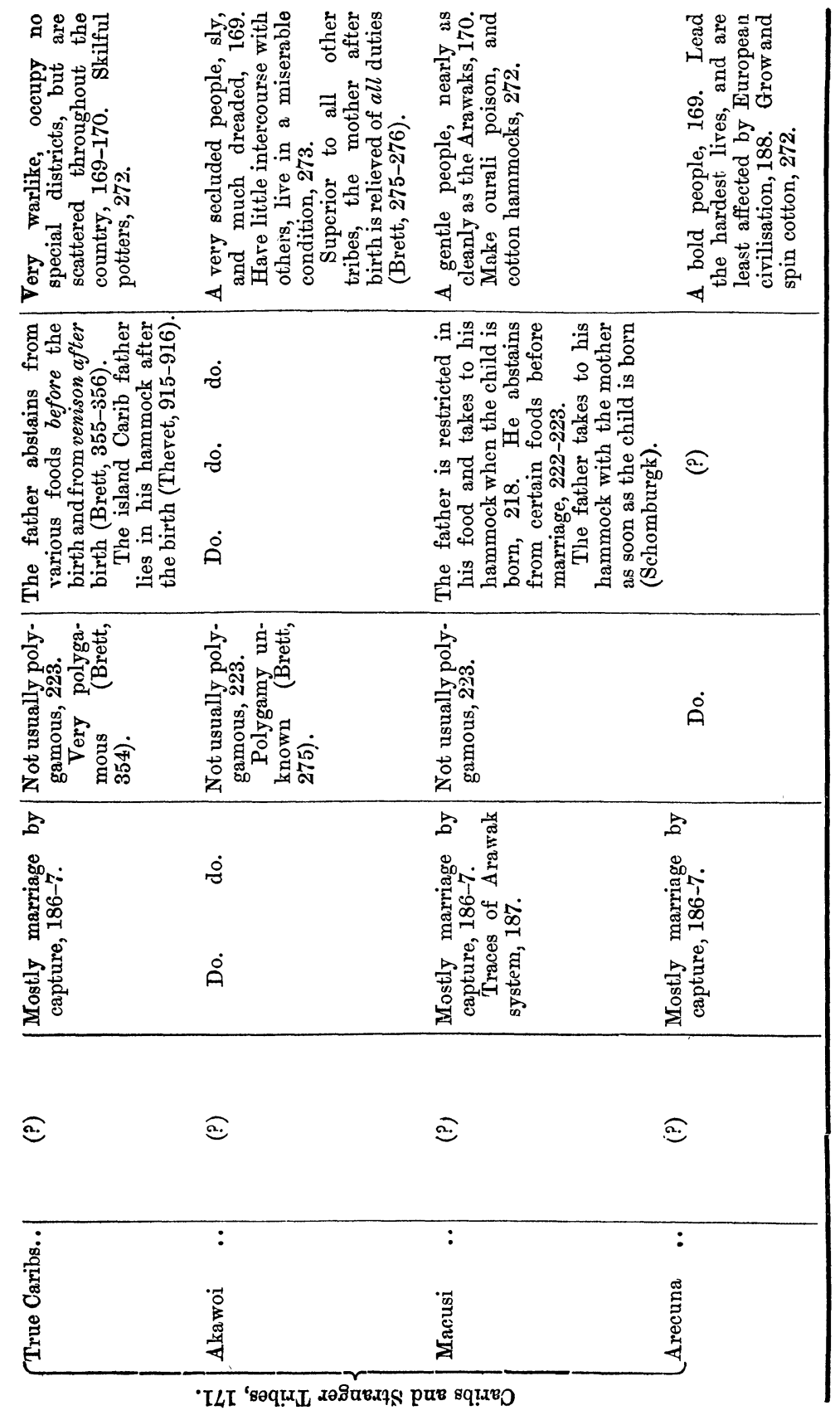








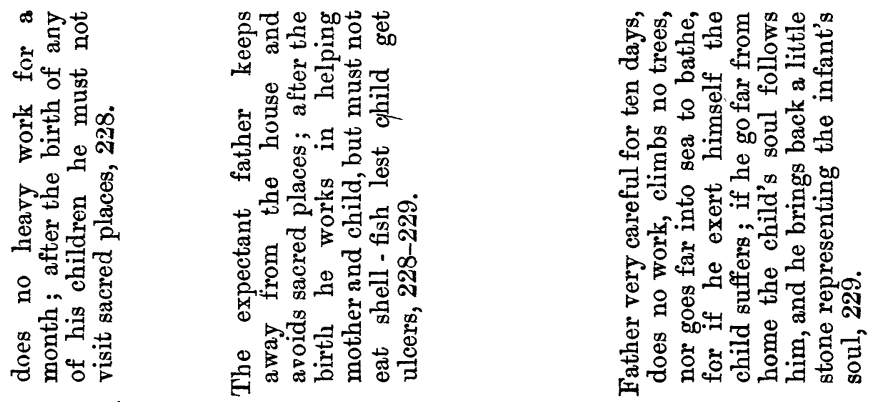

※ั.

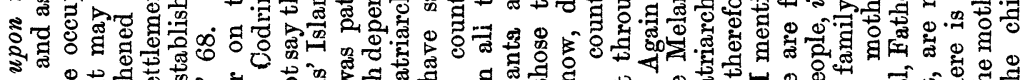

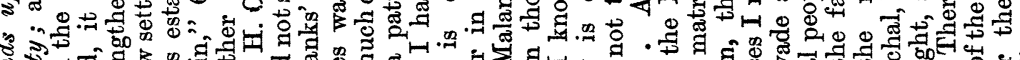

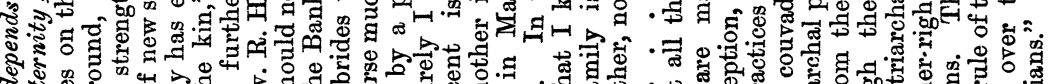
\$ \&

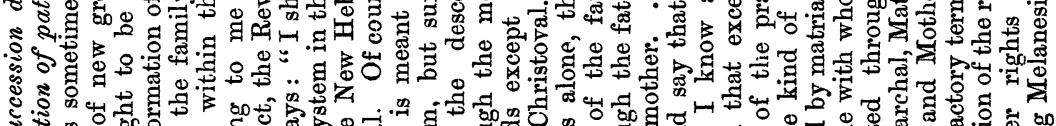

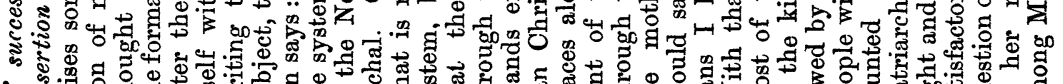

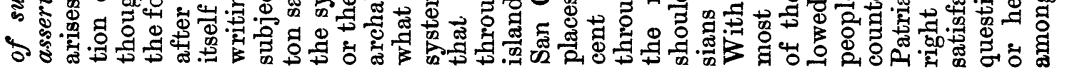

\begin{tabular}{|c|c|}
\hline 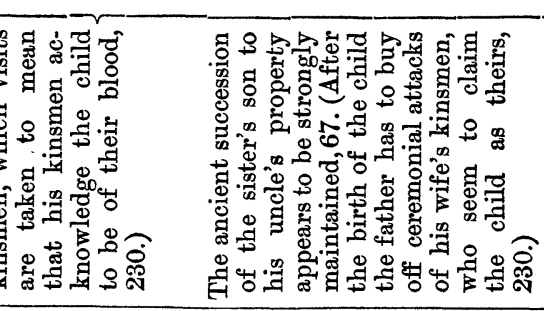 & 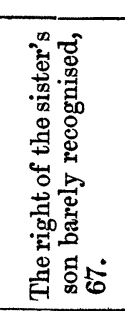 \\
\hline 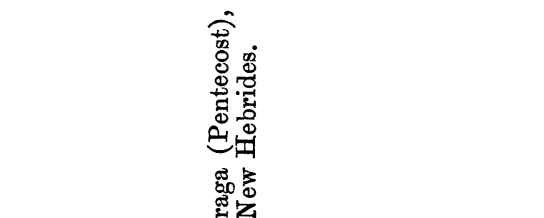 & 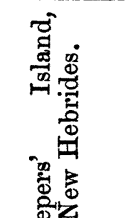 \\
\hline
\end{tabular}

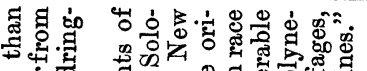

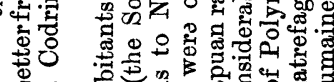

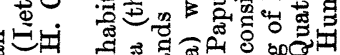

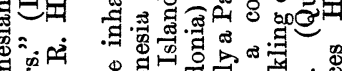
(a)

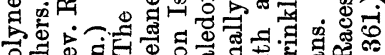

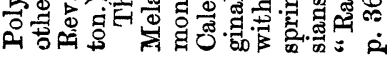


immunity from danger is, however, quite opposed in idea to the prevailing predominant idea in couvade, which consists in abstention on the part of the male parent from certain specified acts lest harm befall the offspring, expected or newly-born, and does not consist in the idea that otherwise dangerous deeds may be committed with impunity; when not pregnant the woman cannot step on the snake withont risk, but when just past delivery she and her husband can do as they please in this matter. We also meet with a new notion that pregnancy or delivery reacts on the male parent, thus we have Mr. im Thurn's anecdote where some Indians refused to allow an Englishman, whose wife was known to be with child, to attempt to catch fish by means of the haiari narcotic, as, in consequence of his wife's state, the haiari would not act and the fish would escape (Timehri I, p. 313). An almost identical case is related by Mr. Kingston (ibid., II, p. 355): “While some (True) Caribs were poisoning the Upper Pomeroon with haiari for fish, I saw one of them rub his shins with the beaten and washed-out haiari. Asking why he did this he told me his wife was with child, and that he could not therefore go into the water without first rubbing his legs with haiari, lest all the fish should sink to the bottom." Here the proposed action of the father does not affect the unborn child, but the unborn child affects the father by causing him to lose his fish, and precautions have therefore to be taken to prevent such a mishap. According to Bachofen this would mean the unborn child claims this man to be its father, which is absurd.

The table previously given of the variations in the practice of couvade shows us that in the larger number of cases the usually unconsidered daily actions of the father affect the welfare of the child that is born; secondly, that the father's acts affect the child that is about to be born; and finally, that the acts affect any child that may be born at any future date. The last-named stage of the custom or belief, namely, that acts committed before marriage may affect any future child, is easy of comprehension to us because it is logically correct, and we may therefore dismiss it without further consideration. But in the second stage we have the curious development of the belief into one which we may term an occult reaction of the expected child on the father, affecting his success in fishing, and also the still more curious idea that the mother of the expected child, if she eat of any of the animal food captured by the tather's dog, will cause that dog to lose its hunting powers. A civilised reasoning man could hardly imagine such an illogical case as this last one.

In the majority of cases where the savage has given an explanation for his practice it implies his belief in a still existing 
connecting, but nevertheless unseen, link between himself and the expected or new-born child. That he does really believe in the existence of some such bond is plain from the care he takes to avoid eating the specified foods which are said to injure the child, and it is plain from his careful abstention from the use of all sharp cutting implements, \&c., with a like object in view. This kind of reasoning is known to us as magic or witcheraft, and it is nothing new to be told that one of the great characteristics of the uncultured mind is a belief in similar occult links, nor have we far to go to gather handfuls of examples. Here are a few :-

A particularly widespread belief is that one which enables an individual to bewitch another by means of articles once belonging to the individual who is to be injured. Thus, while Captain Speke was in Unyoro, the king, Kamrasi, sent some one to steal some grass from the thatch of a Chopi chief, "in order that he might spread a charm on the Chopi people, and gain such an influence over them that their spears could not prevail against the Wanyero" ("Journ. of Disc. Nile," Lond., 1863, p. 531). The Australian Aborigines believe that if an enemy get possession of anything that has belonged to them-even such things as bones of animals which they have eaten, broken weapons, feathers, portions of dress, pieces of skin, or refuse of any kindhe can employ it as a charm to produce jllness in the person to whom they belonged (Jas. Dawson, "Australian Aborigines," 1883 , p. 54). The Patagonian men have their hair brushed out every morning by their wives, sisters, or female friends, "who take care to burn any hair that nay be brushed out, as they fully believe that spells may be worked by evil-intentioned persons who can obtain a piece of their hair or nails" (Lieut. Masters, "Journ. Anthrop. Inst.," 1, 1872, p. 197). To this day the Sussex peasant believes that if a toad get hold of the long back hair of a maiden she will have a cold in her head for so long as it keeps the hair in its mouth. The Pakoos have certain stones with which they cause the death of an enemy by striking his footprint with them "(A. R. Colquhoun, "Amongst the Shans," Lond., 1885, p. 77). In Warwickshire they say "if you burn eggshells. the hens will cease to lay; and if you burn milk, the cows will run dry" (S. Timmins, "Hist. of Warwickshire," Lond., 1889, p. 213). where the burning of the eggshells or milk bewitches the hens or cows. Francis Moore recorded, onehundred and fifty years ago, the existence on the Gambia of a similar belief with regard to boiling milk ("Travels," Lond., 1738, p. 35), while only thirty years ago Captain Speke found the same belief on the Victoria Nyanza (op. cit., p. 163). At Karague he informs us that "any one who ate the flesh of pigs, fish, or fowls, or the bean cailed 
maharague, if he tasted the products of their cows, would destroy their cattle," and as a consequence he and Grant could obtain no milk (op. cit., p. 205). This brings us to the belief that the eating of certain foods will affect the new-born or expected child (a characteristic accompanying belief of couvade) and which was met with by Dr. Livingstone ("Last Journals," London, 1874, II, p. 145), who recorded at Kasonge's village that if the flesh of a specified parrot is eaten by young men their childen will have the waddling gait of the bird.

On one occasion Dr. Moffat found that medicine intended for a man was taken by his wife, under the idea that her drinking it would cure her husband ("Mission Labours," Lond., 1842, p. 591). Once at Goumbi, Du Chaillu brought into camp a live young female gorilla and he tells us "while she was alive no woman who was enceinte, nor the husband of such woman, dared approach her cage. They believe firmly that should the husband of a woman with child, or the woman herself, see a gorilla, even a dead one, she would give birth to a gorilla and not to a man child. This superstition I have noticed among other tribes too, and only in the case of the gorilla;" and elsewhere, on another occasion, when his party brought the body of a dead gorilla into the village, three women "who were pregnant hastened out at the other end with their husbands and nothing could induce them to return till the skin was dried and put away; they could not be convinced but that, if even the husband saw the beast. the wife would bear a young gorilla" ("Explor. and Adv. in Equat. Africa," Lond., 1863, pp. 262 and 305). This is similar to a belief, related by Mr. John G. Bourke, of the Moquis of Arizona, "who do not have the couvade, but in common with the Navajos and Zunis, are strongly imbued with the ideas of spiritual relationship between father and child .... In Keam's store was a little iron figure representing a wrinkled old man smoking a lighted taper; at this figure persons using cigarettes, pipes, or cigars, were in the habit of getting a light without going to the trouble of striking a match. An old Navajo, Ostin-Tzin-cle-he (old man of the fire stick or match), who dropped in one morning, was offered a cigarette, which he accepted, but when invited to light it at the little statue lamp, declined very emphatically. Curious to learn his reason, Keam asked for an explanation. The old fellow said it would be 'bad medicine'; his wife was expecting to present him soon with an increase of family, and were he to light his cigarette at that figure his wife would be sure to have a son just like it. Keam laughed heartily at the, to him, absurd notion, but the old Navajo was not to be driven from his opinions by ridicule. He reiterated what he had said and appealed to several Indians 
standing near-Navajos, with, I think, one or two Moquisthey all concurred in his prejudices ("Snake Dance of Moquis of Arizona," Lond., 1884, p. 236)."

If the Guiana father of the new-born babe eat of the flesh of the agouti, the child will be meagre like that animal, or if he partake of the labba it will be spotted like the labba-in other words, by eating of agouti or labba the father bewitches the expected or new-burn child, just like the Kasonge men who were not allowed to eat the flesh oi certain parrots lest their children should have the waddling gait of the birds, or just as Speke and Grant's eating the flesh of pigs was said to be tantamount to their bewitching the Karague cattle.

Similarly the case of the father not being allowed to use any sharp cutting instrument or heavy tool finds its counterpart in the case of the Kamtschatka husband, as related by G. W. Steller. Saying that women suffer little in childbirth, he continues: " $\mathrm{Zu}$ meiner Zeit passirte, dass ein Weib zu einem raren Exempel ein Kind dergestalt gebahr, dass es mit dem Hintern zuerst kam, und drey Tage in Geburtschmerzen ausstehen musste, die Shamanie gab zur Ursache an dass der Frauen Mann schuld daran wäre, welcher zu der Zeit, da dass Kind in die Geburt trat, einen Schlitten machte, und die Querhölzlein über dem Knie krumm gebeuget, wie man sie nöthig hat, woraus die lächerliche Phantasie der Itälmenen zu sehen" "Beschreibung a. d. 'Lande Kamtschatka," Frankfurt, 1774, p. 351).

The curious case of the father's impossible success at fishing unless he use an antidote, where the father instead of bewitching is himself bewitched, is matched by the tale of the Siberian peasant and his gun, as related by Mr. H. Seebohm ("Siberian Asia," Lond., 1882, p. 71). He had commissioned a peasant to shuot crows, "I asked him why he had neglected my orders. He told me it was unlucky to shoot a crow, that a gun which had once shot a crow would never shoot any other bird afterwards, and he assured me that he had once shot a crow and had been obliged to throw his gun away." Here the dead crow has bewitched the gun, the author of its death.

Schomburgk has told us that when the husband is doing his couvade, he is, amongst other restraints, not allowed to scratch himself with his own finger-nails. The man is, in fact, under a tabu like the Fijian or more like the New Caledonian (Hudson's Bay) women, who, under somewhat allied circumstances, must not "touch their heads with their hands, but keep a small stick wherewith to scratch them" (G. Hamilton, "Journ.Anthrop. Inst.," vii, 1878, p. 206).

If it be possible to trace such a custom, the evidence before us tends to show that originally the father, whatever may have VOL. XXI. 
been the reason, abstained from certain foods, and restricted his daily vocations; then as these fasts and restrictions increased he was bound more or less to stay at home, and ultimately, as it was no hardship on the woman to be turned out soon after delivery, he took her place either, as Quandt and Chavallon suggest, to be out of the way of temptation to do the prohibited deeds, or simply as a matter of necessity almost, for he was bound to keep quiet, and therefore the hammock was the most suitable place for him to keep quiet in. Gradually, from taking the woman's place and being there visited and congratulated by his friends would spring the notion that he too was then and there at that particular period immediately physically concerned in the childbirth. In the meanwhile the fasting went on and other notions, such as the scratching with an agouti tooth, and the special duties imposed on him when he got up, grew up insensibly side by side in the same way as they die out together. With one exception above given, there is no thought on the part of the parents that the custom is practised to show that the father does it to acknowledge the child as his. It is said by anthropologists that originally this was the idea, but now it has been forgotten. Such an argument presupposes the idea, that the savage had instituted a ceremony in remembrance of an event, the event in this case being the transition from the matriarchal to the patriarchal. Now, in the first place, it is quite contrary to the genius of man in the savage state we are studying to institute such ceremonial, and, in the second place, the change has been so gradual as to be almost imperceptible-for, as has been well observed by Dr. Tylor, in these questions of evolution of man's ideas we are dealing with what are in point of time geological periods-and we may take it for granted that the savages themselves have no notion thát they are in any state of transition at all. The Melanesians even in quite initial stages of couvade do not know that they are proving (?) the father's acknowledgment of his child.

To be a real case of record of the change, couvade ought not to be found among the matriarchal people, but it should be met with very largely, if not everywhere, among the matriarchal-patriarchal, and as a survival among the patriarchal. Its existence in the latter, however, is not essential to the proof.

At the outset we are met with its existence where it should not be found-namely, among the Arawaks, a purely matriarchal people and some Melanesians. It may be objected that the Arawaks have copied the custom from their closely allied neighbours, but we have no proof that such is the case, and we know for a fact that the Guiana tribes do not live in peace with one another, and are hence the less likely to copy one 
another's customs. It is difficult to discover more cases of couvade among matriarchal peoples, because at the present day there are comparatively few existing tribes who can be considered purely matriarchal, and also because anthropologists may differ as to where the earlier state ends and the transition state begins. So that while the Rev. Dr. Codrington from personal knowledge considers the Melanesians as decidedly matriarchal (Table III) other anthropologists would see signs of a tendency to change.

We find most of the decided cases of couvade in the transition state, because magic, like other human institutions, has also had its development and also because we are perhaps more acquainted with savage life in this state than we are with it in the other two.

Accepting for a moment the statement that the existence of the custom in the transition state is a sign and record of such transition, then the converse should also be true, and its absence from the matriarchal-patriarchal should prove that this state is not one of transition but one of origin; but this leaves out of all consideration the Australian aborigines who at the present day while being exterminated are in the midst of their transition. While the Australians have much less scope for the exercise of their mental powers they are quite equal mentally to the natives of Guiana, and their medicine men are no whit behind the peiaman in their knowledge of magic. Hence we cannot regard the absence of couvade amongst the Australians as want of mental development, and we should consequently expect to find at all events some trace of its existence, even if only in an embryo stage, among a people who have advanced so far on matriarchal-patriarchal lines.

In the last known state, to us the patriarchal, we find few cases, because when mankind has arrived at that period of his development his general belief in magic has naturally by so much declined, and unconsciously he begins to give it the go by.

Where couvade is found in the transition state it has become to us a sign of the change, that is, we have found the custom and the change side by side, and come to the conclusion that the one is the sign of the other, but from the evidence brought forward in the above pages I am inclined to think such a conclusion untenable. If it be any record at all it may possibly be a record of the change from communal orfrom group marriage to individual marriage, but here too we may well hesitate.

Couvade, like all magic, may be considered one of the expressions of an aberrant form of reasoning, of every-day occurrence with savages, and the wideness of its distribution leads to the conclusion that, while other studies appear to prove that mankind's 
mental progress is along one and the same highway, there is a natural consequent coincident identity of error in his development.

\section{Appendix.}

Though I myself fail to see any connection between couvade and certain phenomena which are occasionally met with in civilised life, yet it is perhaps just as well to record such as I have been able to gather. A "well-known Professor of Philosophy" writes to "Timehri" II, p. 160 :- " If ever you make out the couvade, I suspect you will find that its first origin was a real sympathy between husband and wife. I could tell you (if I had space) one or two very odd stories, where, during pregnancy, the husband, at a distance, was invariably affected by sicknessvomiting in one case. Such things are laughed at by the scientific, but if testimony goes for anything (and perhaps it does not), they are well established." The then editor of "'Timehri" III, p. 149, speaking of this supposed real physico-sympathetic connection between a man and his wife extracts the following from the "Academy":-_" In Mr. York Powell's interesting and able review of ' Grimm's Teutonic Mythology' ('Academy,' Feb. 23) reference is made to the universal belief among our English and Irish peasantry ' that a man will suffer from such ills as are wont to accompany pregnancy, nausea, neuralgia, and the like, if his wife be lucky enough to escape them.' Just to show that folk-lore is in many cases but a too free and illogical argument based on facts, I may perhaps be allowed to say that I am today acquainted with three persons, one living in Sussex, one in London, and one in Northants, who invariably suffer from neuralgia or vomiting when their wives are enceinte, the ladies themselves having a very happy time of it." In the "British Medical Journal" for 26 Sept., 1891, p. 725, Dr. Norris F. Davey reports a somewhat similar case thus:"Many years ago a newly-married farmer and cowkeeper came to reside near Romford. The wife proved to have a distorted pelvis, and I delivered her of her first child by craniotomy. On six subsequent occasions I induced labour at seven and a half to eight months; on one of the latter of these pregnancies there was a doubt as to the date of conception, but the husband confidently confirmed the date of quickening because ' he felt so bad himself at that time.' He was very much hurt when I ridiculed such an idea, and said, ' You may laugh, doctor, but I always feel bad when that happens, without my wife saying anything about it; and why shouldn't I, as I am the father?' This civilised savage (who, I think, came from Wiltshire) was evidently a firm believer in the occult link, but it is 
not an Essex belief, as I never met with any similar fancy during thirty-eight years' practice in that county. "

Finally, the Rev. Dr. Codrington writes me: "I never could get any one in England to take it seriously, but I know the case of a man of purely European blood who had much constitutional disturbance in his wife's pregnancy. I know of another man of mixed blood who was always ill at his wife's confinements. If this happens only in some cases among natives, it would be quite enough, in rny opinion, to make it the proper thing for a father to suffer something; and if one were to declare there was nothing the matter with him, or that it would make no matter to the child, he would be open to the remark that the child was not his." But it appears to me that such a deduction could only arise in the minds of those who see couvade already practised.

\section{NOTE.}

Since going to press I have seen the original wording of the custom described by Mr. D. F. A. Hervey on the Endau (Malay Peninsula), and which Wilken classes under couvade. It runs: "A curious superstition prevails among the Madek people, which, so long as children are unable to walk, prevents their parents from using as food certain fish and animals; as soon as the little ones have acquired the use of their legs this restriction is removed, and the parents are once more able to indulge in what has so long been pantang, or 'forbidden.' Should this superstition not be complied with, and any parent eat of any of the forbidden creatures during the period of restriction, the children are supposed to be liable to an illness called busong, arising, according to the Malay, from prut kumbong, or swollen stomach. . . ." ("Jour. Straits Branch Roy. Asiatic Soc.," No. 8, p. 120, 1882.)

\section{Discussion.}

Mr. BRABROOK said: Having had the opportunity of reading Mr. Ling Roth's excellent paper in MS., I am desirous of adding a few remarks. I confess I wish he had been able to treat the subject on the lines of our President's epoch-making paper on the methods of anthropological research, and I regret I have not had opportunity or materials to supply the defect; but I thankfully avail myself of the wealth of information which Mr. Ling Roth has collected. He very justly remarks that the custom seems to us an absurd one; but it is not altogether so when fairly considered; for what does it imply? 1. A condition of monogamy and conjugal fidelity. 2. The acknowledgment of hereditary succession through the father. 3. Domestic affection 
and self-sacrifice for the sake of the child. 4. Highly artificial religious or superstitious belief. These are all indications of progress in civilisation, and in combination they negative the idea that the custom is a mere absurdity. Writers of high authority have suggested that the primitive condition of mankind was one of promiscuity, and that an early stage of development was that of reckoning kinship through the mother, on the cynical ground that that at least is certain; and though their conclusions have been challenged and met by arguments of some weight, I am not concerned to dispute them for the present purpose; for if they be accepted, at what a distance from primitive savagery does not the couvade place us?

The statement that the couvade implies a condition of monogamy and conjugal fidelity, though it seems to be obviously and necessarily true, requires some consideration in the light of the facts collected by Mr. Ling Roth. It must be admitted that some of the peoples mentioned in his paper have not the reputation of possessing these qualities. Passing over the European peoples in whom traces of the custom have been observed, the peoples of Borneo, China, New Britain, and Nicobar may be counted as monogamous. Among others of those he mentions polygamy is rare; among some it extends over a portion only of the community ; in one case polygamy exists, but the couvade is used as a proof of paternity; and with regard to the Eskimo, whom it is impossible to claim as models of conjugal fidelity, it would seem to be doubtful whether the customs observed really amount to couvade. It is possible that couvade may have existed in some polygamous communities for the purpose of indicating the child of the favourite wife, who was to be adopted as heir; but if that be so, the custom itself would become the sign and symbol of a transition to monogamy, for it would raise the preferred mother to the position of sole wife and reduce the others to that of concubines. That couvade should exist in combination with actual polygamy, that is, that the man should be compelled to practise it on the birth of every child of a numerous body of wives, is so incredible that any evidence there may be of it must be open to grave doubt.

The second point, that the couvade implies the acknowledgment of hereditary succession through the father, is equally obvious. It implies it, not only as an admission of scientific belief, but as an actual fact in jurisprudence. The third, that it evinces domestic affection and self-sacrifice for the sake of the child, is confirmed by the circumstance that to this day the American tribes, among whom couvade has been most general, are marked by singular tenderness towards their children. The fourth point, its religious basis, I postpone for the present.

The problem then is, how reasonably to account for the adoption of a practice of apparent absurdity, among peoples possessing moral qualifications of this high character. Has that been solved by any of the explanations yet offered ? I think not, and agree with Mr. Ling Roth that none of them is quite satisfactory. May 
I venture to offer a suggestion as to a manner in which, as it appears to me, the custom may have arisen ? I figure to myself a people among whom monogamy is an institution, and I am willing to think it possible that among the lower classes at least, conjugal fidelity may not have been strictly observed. Let me suppose a supreme ruler of this people, married to one wife and really attached to her, and possessed with the idea of securing to his offspring through her the succession to his authority. The time approaches for her delivery; partly from affection for her, partly from anxiety for the welfare of the expected child, he secludes himself in his dwelling, withdraws for the time from all affairs of state, and watches closely for a shorter or longer period over the infant. I assume him to be a man of such force of character that conduct like this on his part would seem to his people not an eccentricity to be laughed at, but rather an example to be followed. The subordinate chiefs would see in it something to mark them off from the common rank, and would adopt and follow it as a custom suitable to persons of aristocratic birth, who had something to leave to their children, and desired by this solemn withdrawal from other matters on such an occasion to mark the birth of an heir to an important position, and to testify to the purity of his blood. Once established as an aristocratic custom, it would soon become universal; for nothing spreads more widely than an observance supposed to be fashionable. In a short time the couvade would become an established institution among all classes. Once an established institution, the histrionic and farcical elements of going to bed, being dieted and physicked, would come in time to be added; and finally, the religious and superstitious theories to account for what had ceased to be explainable, its origin having been wholly forgotten, would have been developed. Where and at what time this may have happened, who can say? I should be inclined to place it somewhere in South America, where there has been ample space and time for many customs to grow up and take root, and be transplanted into Asia, and wander into many other parts of the world. All I plead for is, that when we meet with a problem of this kind we should try to solve it by the readiest means-put it to ourselves, What are the circumstances in which a man would naturally or instinctively act in such a way? avoid all hypotheses which imply sudden changes, and select those which involve only gradual and unconscious variations.

Have we any survivals of anything like the couvade among ourselves? I fancy not. It is true that custom requires the husband to fetch the doctor and the nurse, and that he endures snubs on all sides upon these interesting occasions; but my impression is that these date no earlier than the custom of employing man midwives, which is not I believe two hundred years old. The custom of the attendance of Ministers of State at the birth of a possible heir to the throne is one which has the same rational origin, and the same irrational persistence, as that of the couvade. 